\title{
IbW PEMBERDAYAAN MASYARAKAT MELALUI PENGEMBANGAN BUDIDAYA IKAN LELE SISTEM BIOFLOK DI DESA BLANGKUALA, MEUKEK, ACEH SELATAN
}

\author{
Teungku Nih Farisni ${ }^{1}$, Uswatun Hasanah ${ }^{2}$, Nourmalina Arphi ${ }^{3}$ \\ ${ }^{1}$ Prodi ilmu Kesehatan Masyarakat, Fakultas Kesehatan Masyarakat, \\ Universitas Teuku Umar, Meulaboh Aceh Barat \\ ${ }^{2}$ Prodi Perikanan, Fakultas Perikanan dan Ilmu Kelautan, \\ Universitas Teuku Umar Meulaboh Aceh Barat \\ ${ }^{3}$ Prodi Teknologi Hasil Pertanian, Fakultas Pertanian, \\ Universitas Syiah Kuala, Banda Aceh \\ Email: uswatun.hasanah@utu.ac.id
}

\begin{abstract}
ABSTRAK
Desa Blang Kuala Kecamatan Meukek, Kabupaten Aceh Selatan memiliki potensi daerah yang belum termanfaatkan secara maksimal. Salah satunya adalah potensi di bidang perikanan. Program Kemitraan Wilayah (PKW) oleh Tim PKW LPPM Universitas Teuku Umar bekerjasama dengan mitra LPPM Universitas Syiah Kuala dan Pemerintahan Kabupaten Aceh Selatan bertujuan untuk memaksimalkan potensi yang ada melalui pemberdayaan masyarakat. Metode yang akan digunakan untuk pelaksanaan PKW adalah metode pemberdayaan masyarakat dengan yang mengupayakan partisipasi masyarakat untuk belajar dan beraktivitas secara berkelanjutan dalam rangka meningkatkan kualitas hidup mereka. Aktivitas-aktivitas yang dilaksanakan selama proses pendampingan adalah pembangunan tempat Demontrasi Plot (DEMPLOT) budidaya lele sistem bioflok, pelatihan pembuatan konstruksi kolam budidaya sistem bioflok, pelatihan pemeliharaan budidaya lele sistem bioflok, sampai dengan pendampingan pemanenan. Hasil kegiatan IbW Kecamatan Meukek diharapkan dapat berkesinambungan dan menjadi pusat pembelajaran dan pelatihan budidaya lele sistem bioflok bagi masyarakat di desa Blang Kuala khususnya dan masyarakat Aceh Selatan pada Umumnya. Sehingga dengan adanya tempat kegiatan budidaya sistem bioflok ini dapat meningkatkan pendapatan keluarga secara berkesinambungan sehingga kesejahteraan dapat dirasakan oleh masyarakat yang akan berefek pada peningkatan intensitas keterlibatan masyarakat dalam program pembangunan yang dicanangkan pemerintah.
\end{abstract}

Kata Kunci: Budidaya Lele System Bioflok, Demplot, PKW

PENDAHULUAN

Program Program pengembangan

masyarakat dapat dilakukan berdasarkan kearifan lokal berupa peningkatan partisipasi masyarakat dan berjalan secara berkelanjutan (Amanah, 2005). Pengembangan masyarakat merupakan kegiatan yang dilakukan bersama komunitas masyarakat dengan cara meningkatkan partisipasi aktif masyarakat dalam rangka memenuhi kebutuhan hidup dan menyelesaikan persoalan-persoalan dialami oleh komunitas masyarakat (Darmansyah, 2016). Kegiatan pengembangan masyarakat dapat berupa peningkatan keterampilan melalui pelatihan peningkatan kemampuan dalam mengolah sumber daya alam (Ihsan, 2002).

Pemberdayaan masyarakat merupakan hal yang penting untuk dilakukan karena melalui pemberdayaan, kehidupan masyarakat menjadi lebih baik. Pemberdayaan yang yang dilaksanakansesuai dengan prosedur dan model 
pemberdayaan partisipative salah satunya kegiatan pemberdayaan pembudidaya ikan (Zulkarnain, 2015).

Proses pemberdayaan pembudidaya ikan dilakukan di desa Blang Kuala Kecamatan Meukek Kabupaten Aceh Selatan. Kabupaten Aceh Selatan dengan ibukotanya Tapaktuan, merupakan salah satu Kabupaten di Provinsi Aceh yang dengan ketinggian wilayah rata-rata sebesar 25 meter di atas permukaan laut (mdpl). Luas Kabupaten Aceh Selatan adalah 4.005,10 $\mathrm{Km} 2$. Karena letaknya di kaki gunung, sehingga banyak dijumpai sumber mata air dengan debit air yang cukup besar dan mengalir sepanjang tahun. Sumber mata air yang ada sudah digunakan oleh masyarakat setempat untuk pengairan sawah dan kebutuhan sehari-hari warga, juga digunakan untuk memelihara ikan di kolam dengan teknologi yang masih tradisional. Jenis ikan yang dibudidayakan pun terbatas pada ikan gurame dan mujair, karena ikan tersebut hanya untuk dikonsumsi sendiri. Seiring permintaan pasar terhadap ikan air tawar yang terus meningkat, maka saat ini banyak masyarakat yang mulai membudidayakan ikan nila dan lele. Dalam hal ini pembudidaya sangat memerlukan informasi yang berhubungan dengan hal-hal teknis dalam kegiatan budidaya ikan lele secara super intensif berbasis bioflok. Kendala yang dihadapi oleh pembudidaya dalam hal budidaya ikan lele karena pengetahuan pembudidaya tentang ikan lele masih minim. Kendala tersebut antara lain: tingginya serangan penyakit pada ikan lele, pakan sangat banyak, dan pertumbuhan ikan yang masih lambat.

Guna memberdayakan masyarakat desa Blang Kuala di bidang perikanan, dilakukanlah pendampingan masyarakat dalam program Kemitraan Wilayah (PKW) yang diadakan oleh TIM PKW LPPM Universitas Teuku Umar Meulaboh, bekerjasama dengan LPPM UNSYIAH dan Pemerintahan Aceh Selatan. Pengembangan ini akan tercipta jika terbangun komunitas masyarakat yang solid dan mandiri dalam menjalankan program yang sedang dilaksanakan. Kegiatan ini akan berjalan dengan baik jika antara pendamping dengan komunitas masyarakat saling terkait dalam melaksanakan kegiatan tersebut dengan cara melakukan transfer pengetahuan, pembinaan, dan pelatihan sehingga tercipta program yang menghasilkan output dan outcome yang optimal.

Setelah kegiatan ini mampu berjalan dengan baik selanjutnya diharapkan mampu tercipta kader-kader baru yang mampu mengajarkan apa yang mereka sudah miliki kepada orang lain sehingga dampak program dapat lebih meluas. Tujuan program pendampingan adalah berkembangnya inovasi dalam pemberdayaan masyarakat melalui pendampingan dalam kegiatan: (1) Pembangunan Demonstrasi Plot (DEMPLOT) Budidaya lele sistem bioflok, (2) Budidaya lele Sistem Bioflok (3) Pendampingan Kelompok.

\section{METODE PELAKSANAAN}

Lokasi kegiatan pendampingan masyarakat terletak di Desa Blang Kuala, Kecamatan 
Meukek, Aceh Selatan. Pelaksanaan program pendampingan dimulai sejak bulan April 2017. Pendekatan pelaksanaan program pendampingan yang digunakan adalah metode partisipatif yang artinya bahwa masyarakat ditempatkan sebagai subjek dalam setiap aktivitas kegiatan. Pola pendekatan ini mampu meningkatkan persepsi dan motivasi dari masing- masing anggota agar program dapat berjalan dengan baik. Komitmen dari tiap anggota yang telah terbangun dapat mewujudkan kemandirian dan keberlanjutan dalam pelaksanaan program. Tahapan pelaksanaan program kegiatan menjadi dua yaitu tahapan pendampingan teknis dan pendampingan partisipatif.

1. Kegiatan cara pembangunan Tempat Demonstrasi Plot (DEMPLOT) budidaya system bioflok dilakukan bulan September Desember tahun 2017.

2. Kegiatan Pelatihan dilakukan baik melalui materi budidaya system bioflok berupa cerama, diskusi dan demonstrasi

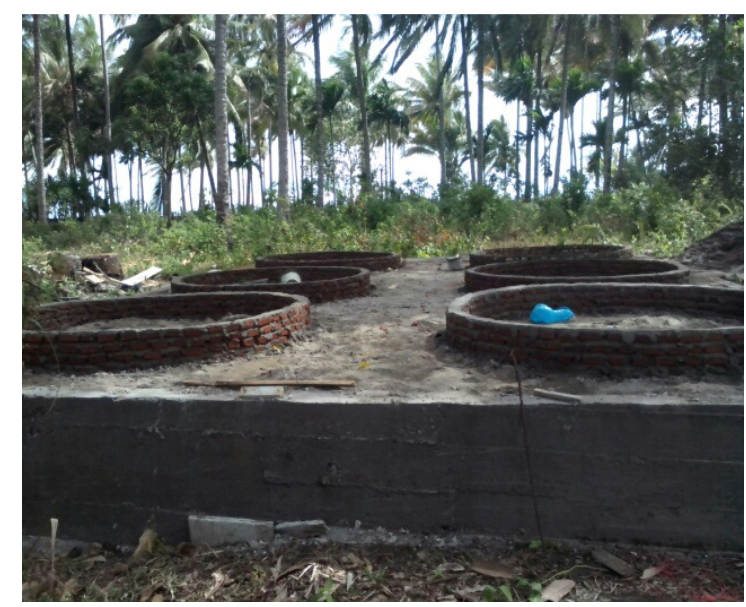

A
3. Kegiatan pendampingan dilakukan dari awal pembangunan DEMPLOT, tebar benih ikan lele, pemeliharaan hingga pemanenan. Dilakukan bulan Maret sampai dengan agustus 2018. Masyarakat yang terlibat dalam kegiatan budidaya lele teknologi bioflok sebanyak 15 orang.

\section{HASIL DAN PEMBAHASAN}

\section{Pembangunan Demplot budidaya lele Sistem Bioflok}

Kegiatan pembangunan DEMPLOT

Budidaya lele sistem Bioflok di laksanakan di desa Blang Kuala kecamatan Meukek Kabupaten Aceh Selatan. Proses Rangkaian kegiatan diawali dengan pembentukan kelompok dari anggota masyarakat berjumlah 15 orang, pembentukan kelompok disepakati nama kelompok yaitu UJOENG BATEE. Kelompok yang sudah terbentuk diberikan pengetahuan dasar bagaimana membangun tempat budidaya dengan Pembangunan pondasi dengan bentuk kolam bulat dengan diameter 2 (Gambar 1).

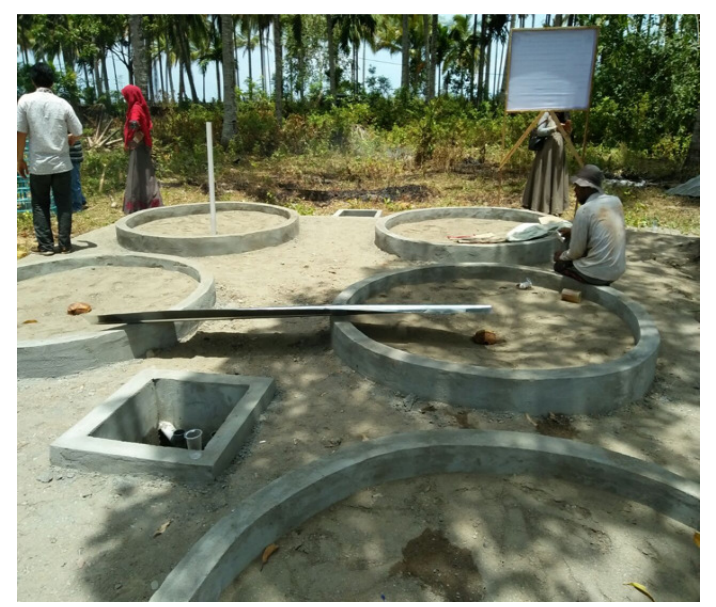

B

Gambar 1. Proses pembuatan pondasi kolam; (A) Pembuatan pondasi dan pembentukan kolam; (B) Pembuatan saluran pembuangan air. 
Logista

Jurnal Ilmiah Pengabdian kepada Masyarakat

Setelah pondasi terbentuk, kelompok secara bergotong royong selanjutnya memasang kolam bulat dengan kontruksi besi wire mesh dan
Vol. 3 No.1 Tahun 2019

ISSN: 2579-6283 E-ISSN: 2655-951X

terpal bundar dengan diameter 2 dapat dilihat pada gambar 2 .

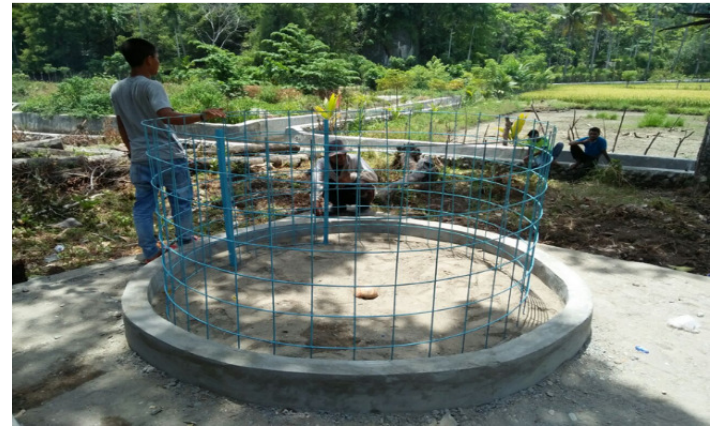

A

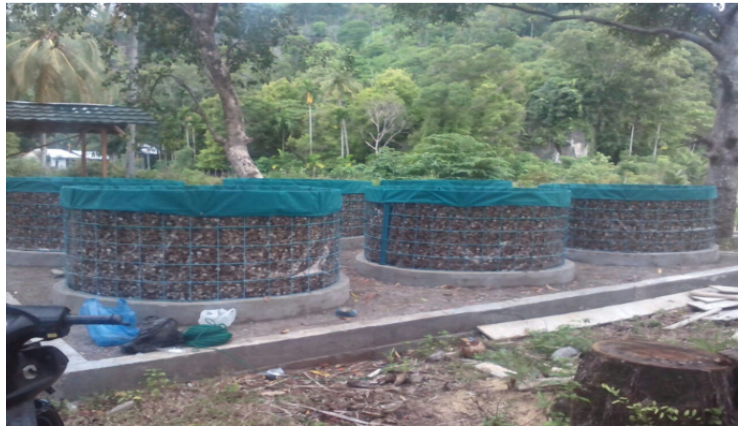

B

Gambar 2. Proses Pemasangan kolam konstruksi besi dan terpal bundar; (A) Pemasangan Besi wire Mesh dengan diameter 2; (B) Kolam bioflok yang sudah siap untuk digunakan

Kegiatan selanjutnya adalah pembangunan rumah bioflok, tujuannya untuk melindungi dari cahaya langsung masuk kedalam kolam dan juga untuk keamanan kolam dari binatang serangga dan lainnya dan juga estetikanya lebih menarik.Rumah yang dibangun menggunakan kayu, sekeliling kolam dan atapnya di tutup dengan penutup dari plastik yang dapat menyerap sinar UV. Persiapan selanjutnya adalah pemasangan listrik, blower dan pompa air. kegiatan ini dapat dilihat pada gambar 3 dan 4.
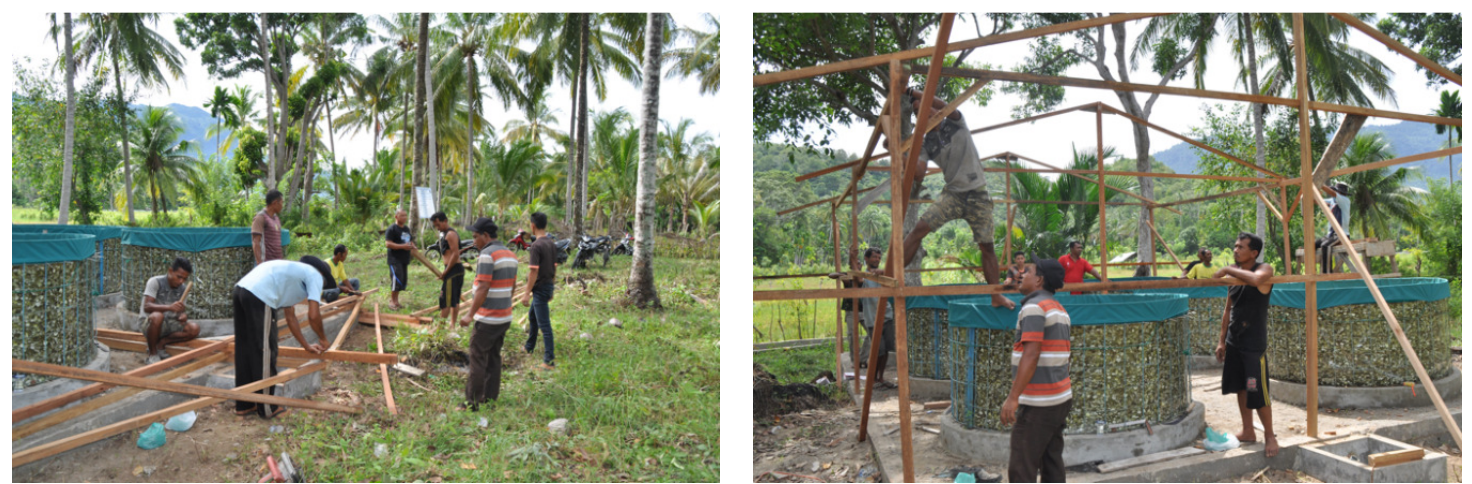

Gambar 3. Pembangunan Kerangka kayu Bangunan Rumah Budidaya Sistem Bioflok. 

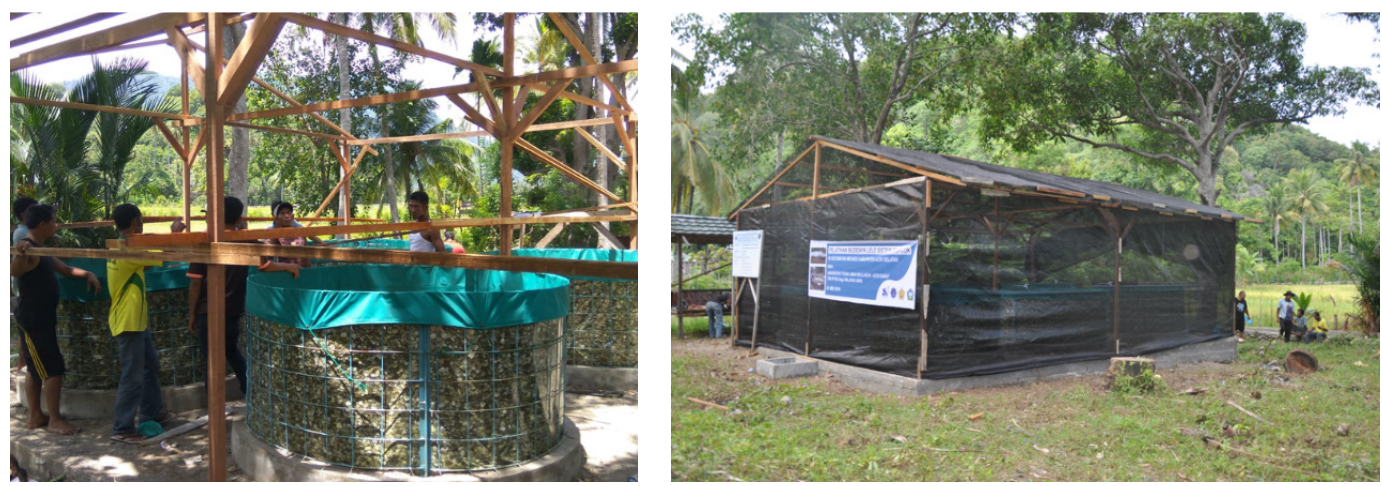

Gambar 4. Bangunan Rumah Budidaya Sistem Bioflok siap untuk digunakan

\section{Pelatihan budidaya Ikan Lele sistem Bioflok}

Pelatihan bubidaya lele sistem bioflok dilaksanakan di DEMPLOTbudidaya sistem bioflok di desa Blang Kuala Meukek, Aceh Selatan. Pesertanya juga kelompok UJOENG BATEE. Diharapkan kelompok ini dapat menjadi pelopor untuk masyarakat sekitarnya
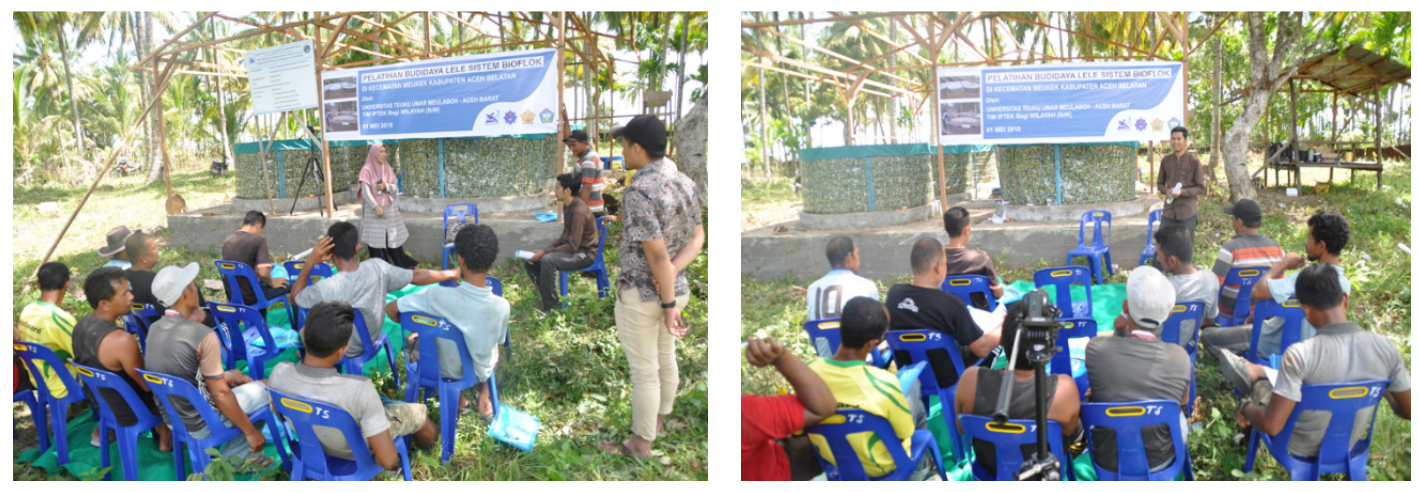

Gambar 5. Pelatihan Budidaya Lele Sistem Bioflok di kelompok UJOENG BATEE, desa Blang Kuala, Kec. Meukek, Kab. Aceh Selatan.
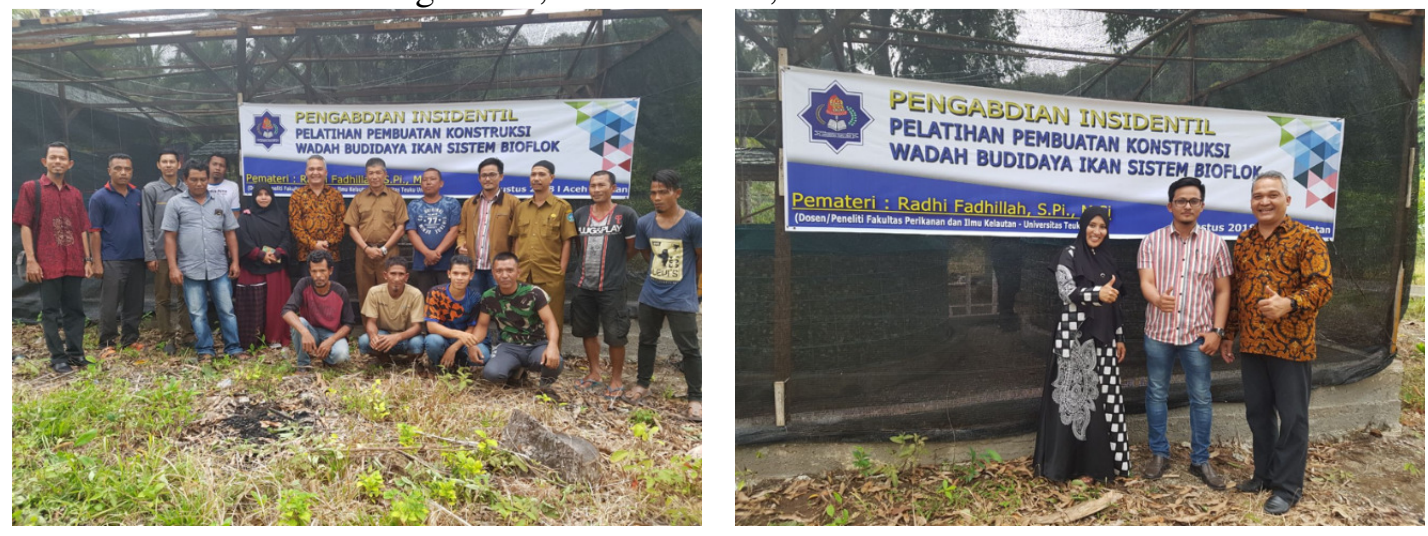

Gambar 6. Pelatihan Pembuatan Konstruksi Wadah Budisaya ikan Lele Sistem Bioflok di kelompok UJOENG BATEE, desa Blang Kuala, Kec. Meukek, Kab. Aceh Selatan. 
Logista

Jurnal Ilmiah Pengabdian kepada Masyarakat

\section{Pendampingan}

Pemberdayaan masyarakat di desa Blang Kuala sudah berjalan 2 tahun. Konsepsi pemberdayaan merupakan upaya mencari solusi dan tantangan sosial, ekonomi dan lingkungan yang menjamin keberlanjutan pembangunan (Vasilescu, 2010).

Slamet (2003) memberikan pengertian pemberdayaan adalah kemampuan, berdaya, mengerti, paham, termotivasi, berkesempatan, dapat memanfaatkan peluang, berenergi, mampu bekerja sama, tahu berbagai alternatif, mampu mengambil keputusan, berani mengambil resiko, mampu mencari dan menangkap informasi dan mampu bertindak sesuai situasi. Pemberdayaanmasyarakat merupakan upaya untuk memberikan motivasi dan dorongan kepada masyarakat agar mampu menggali potensinya dan berani bertindak mengembangkan diri, sehingga terbentuk kemandirian dan tidak tergantung dengan pihak lain. Ada dua faktor yang mendapat perhatian dalam budidaya ikan lele berbasis bioflok pada masyarakat, yaitu mengidentifikasi kompetensi dasar masyarakat dan stakeholder kunci. Kompetensi dasar meliputi keterampilan, pengalaman, kemampuan, pembelajaran kolektif dan modal kompetisi lainnya. Sementara stakeholder kunci meliputi konsumen, investor, pekerja, suplayer dan pemerintah (O'Brien, 2001).

Kelompok pembudidaya yang mengikuti program budidaya ikan lele berbasis teknologibioflok mendapat manfaat dalam
Vol. 3 No.1 Tahun 2019

ISSN: 2579-6283 E-ISSN: 2655-951X

membudidayakan ikan lele yaitu peningkatan produksi, pemanfaatan lahan sempit dan mengurangi bau dalam budidaya lele. Hal ini dirasakan oleh pembudidaya karena budidaya lele berbasis teknologi bioflok belum pernah dilakukan sebelumnya.

Ada dua prinsip pendekatan yang dilakukan dalam kegiatan pendampingan budidaya ikan lele berbasis bioflok, yaitu pendekatan teknis dan partisipatif. Pendekatan teknis, yaitu pendampingan kepada masyarakat mengenai keberhasilan pemeliharaan ikan lele berbasis bioflok. Melalui pelatihan, pembudidaya dilatihcara membuat rumah budidaya, manajemen budidaya dan pengobatan atas penyakit ikan lele hingga membantu pemasarannya.Penguatan kelembagaan dilakukan dengan hingga terbentuknya Kelompok Usaha Bersama (KUBE). Diharapkan KUBE bisa menjadi solusi dalam mengatasi kendala usaha kelompok terkait dengan bahan baku, akses modal dan pemasaran. Upaya kelembagaan tersebut tidak berarti menghapus peran-peran dan posisi pedagang distributor dalam rantai pemasaran produk perikanan, tujuan utamanya adalah merubah pola relasi yang merugikan pembudidaya dan membuat pola distribusi lebihefisien, merata dan terbuka dengan pemangkasan rantai tata niaga yang tidak menguntungkan.

Pengembangan kelompok pembudidaya ikan dilakukan dengan menciptakan iklim yang kondusif dan kerjasama yang sinergis antar 
berbagai pihak yang terkait dalam pembangunan akuakultur, yaitu pendamping atau penyuluh, pembudidaya ikan, dan kelembagaan agribisnis yang memfasilitasi usaha akuakultur, seperti lembaga keuangan yang menyediakan modal usaha, lembaga penyedia input produksi, lembaga penyedia informasi, dan lembaga yang
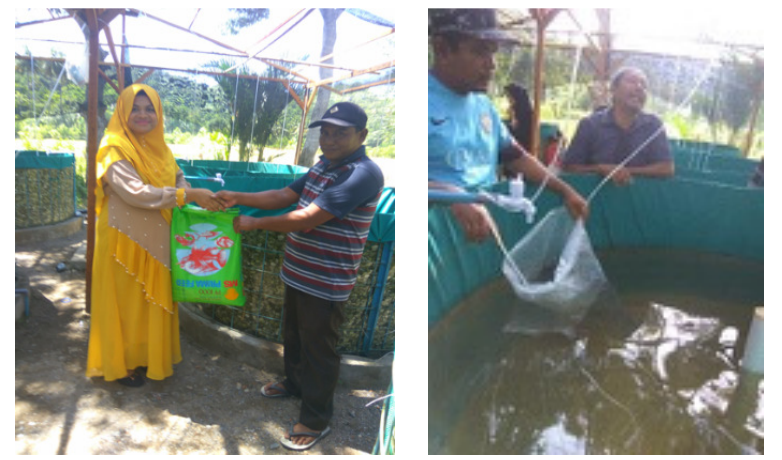

memasarkan ikan. Dalam hal ini, peran kelembagaan yang ada bagi pembudidaya ikan sangat penting untuk meningkatkan keberdayaan pembudidaya ikan dengan memanfaatkan potensi dan fungsi berbagai pihak tersebut (Fatchiya, 2010).
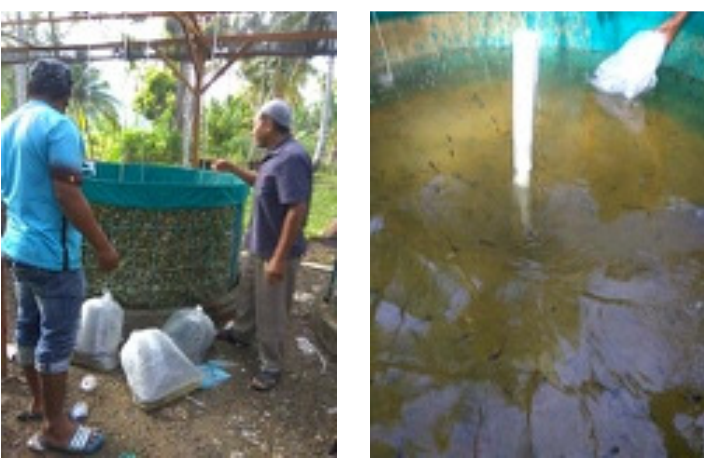

Gambar 7. Pemberian Bantuan Benih dan pakan serta pendampingan kelompok KUBE

UJOENG BATEE pada penebaran benih lele untuk budidaya pembesaran sistem bioflok.

Pendampingan terhadap kelompok KUBE UJOENG BATEE terus dilakukan pada masa pemeliharaan sampai pemanenan. Untuk panen perdana lele dengan pembesaran sistem bioflok, turut di saksikan oleh bapeda dan dinas perikanan aceh selatan dan juga dekan Perikanan dan Ilmu Kelautan Universitas Teuku Umar. Tujuannya adalah untuk memberikan semangat bagi kelompok dan juga kerjasama yang terus bersinergis untuk keberlanjutan program ini, sehingga dapat dirasakan tidak cuma oleh kelompok UJOENG BATEE, tapi juga masyarakat desa Blang Kuala, sehingga dapatdijadikan pemasukan dan menupang perekonomian keluarga. Serangkaian proses panen perdana dapat dilihat pada gambar 8 .
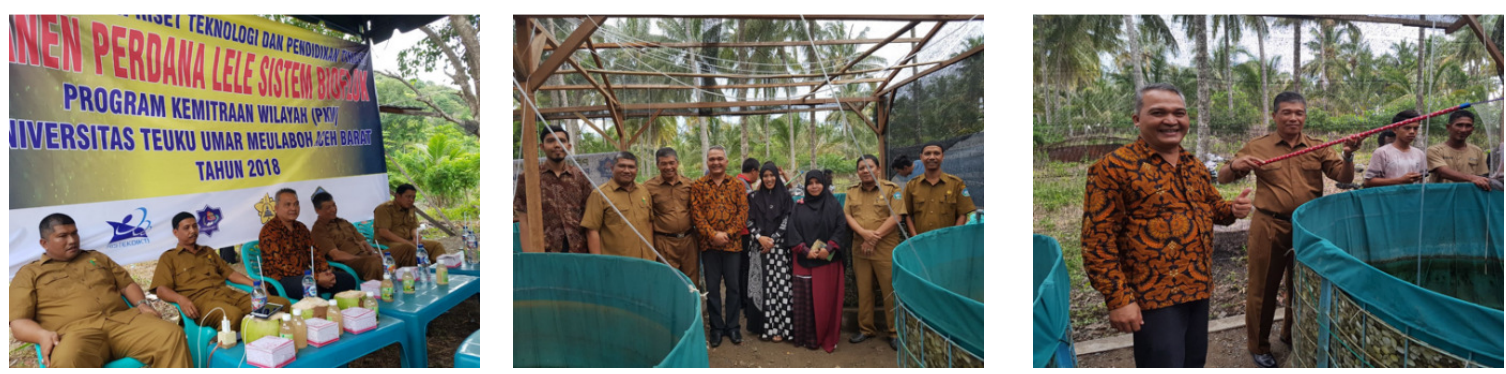

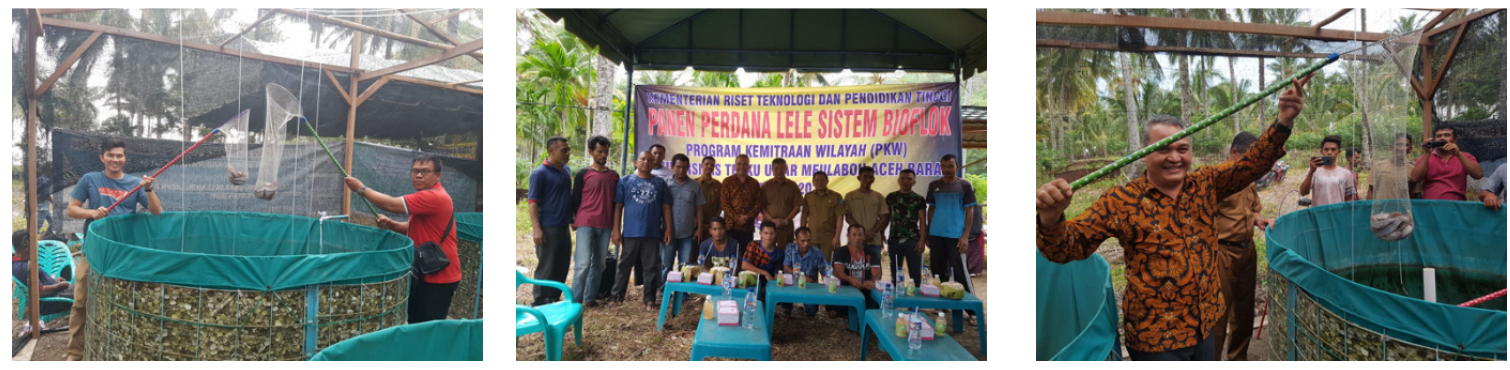

Gambar 8. Serangkaian kegiatan pendampingan panen perdana budidaya lele system bioflok kelompok UJOENG BATEE desa Blang Kuala, Kecamatan Meukek, Kabupaten Aceh Selatan

\section{Pembahasan}

Pemberdayaan masyarakat di des Blang Kuala telah berjala selama dua tahun. Konsepsi pemberdayaan merupakan upaya mencari solusi dan tantangan sosial, ekonomi dan lingkungan yang menjamin keberlanjutan pembangunan (Vasilescu, 2010).

Ada dua faktor yang mendapat perhatian dalam budidaya ikan lele berbasis bioflok pada masyarakat, yaitu mengidentifikasi kompetensi dasar masyarakat dan stakeholder kunci. Kompetensi dasar meliputi keterampilan, pengalaman, kemampuan, pembelajaran kolektif dan modal kompetisi lainnya. Sementara stakeholder kunci meliputi konsumen, investor, pekerja, suplayer dan pemerintah (O’Brien, 2001).

Ada dua prinsip pendekatan yang dilakukan dalam kegiatan pendampingan budidaya ikan lele berbasis bioflok, yaitu pendekatan teknis dan partisipatif. Pendekatan teknis, yaitu pendampingan kepada masyarakat mengenai keberhasilan pemeliharaan ikan lele berbasis bioflok. Melalui pelatihan, pembudidaya dilatih cara membuat rumah budidaya, manajemen budidaya dan pengobatan atas penyakit ikan lele hingga membantu pemasarannya.
Penguatan kelembagaan dilakukan dengan hingga terbentuknya Kelompok Usaha Bersama (KUBE) UJOENG BATEE. Diharapkan KUBE UJOEN BATEE bisa menjadi solusi dalam mengatasi kendala usaha kelompok terkait dengan bahan baku, akses modal dan pemasaran.

Pengembangan kelompok pembudidaya ikan dilakukan dengan menciptakan iklim yang kondusif dan kerjasama yang sinergis antar berbagai pihak yang terkait dalam pembangunan akuakultur, yaitu pendamping atau penyuluh, pembudidaya ikan, dan kelembagaan agribisnis yang memfasilitasi usaha akuakultur, seperti lembaga keuangan yang menyediakan modal usaha, lembaga penyedia input produksi, lembaga penyedia informasi, dan lembaga yang memasarkan ikan. Dalam hal ini, peran kelembagaan yang ada bagi pembudidaya ikan sangat penting untuk meningkatkan keberdayaan pembudidaya ikan dengan memanfaatkan potensi dan fungsi berbagai pihak tersebut (Fatchiya, 2010).

Dari hasil evaluasi awal dapat diketahui bahwa sebelum kegiatan pelatihan dilakukantingkat pengetahuan sebagian besar 
masyarakat Blang Kuala masih rendah dan memang belum pernah tahu teknologi budidaya sistem bioflok. Karena minimnya informasi terkait perkembangan teknologi bioflok pada ikan lele. oleh karena itu, pada masa yang akan datang, sebaiknya dinas terkait dan pengurus kelompok pembudidaya ikan sering melakukan pertemuanuntuk mensosialisasikan perkembangan teknologi budidaya lele berbasis teknologi bioflok. Sosialisasi tersebut dapat dilakukan kepada semua masyarakat yang ingin berkecimpung dibidang budidaya ikan lele.

Tingkat partisipasi para peserta selama kegiatan pelatihan berjalan sangat tinggi. Hal ini dapat dilihat dari antusiasme dan peran aktif peserta. Respon peserta sangat baik karena seluruh peserta sangat tertarik dengan materi pelatihan yang disampaikan. Selain itu mereka haus akan informasi dan pengetahuan baru yang berkaitan dengan perkembangan teknologi budidaya ikan air tawar, khususnya untuk aspek teknologi bioflok pada budidaya ikan lele.

Dengan demikian kegiatan pemberdayaan ini telah dapat meningkatkan pengetahuan dan keterampilan para pembudidaya ikan mengenai proses budidaya ikan lele berbasis teknologi bioflok. Diharapkan pengetahuan dan keterampilan yang mereka miliki dapat diterapkan secara menyeluruh dan pada gilirannya dapat meningkatkan produksi ikan lele sebagai salah satu komoditas air tawar. Target yang ingin dicapai dari kegiatan ini adalah meningkatnya kesejahteraan para pembudidaya ikan di Blang Kuala Kecamatan Meukek.

\section{KESIMPULAN}

Program pemberdayaan masyarakat melalui kegiatan budidaya ikan lele sistem bioflok di desan Blang Kuala kecamatan Meukek, kabupaten Aceh Selatan bertujuan meningkatkan keterampilan dan pendapatan kelompok KUBE UJOENG BATEE telah berjalan, melalui pemberian bantuan DEMPLOT dengan 6 kolam terpal berdiameter 2 meter dengan benih dan pakan satu siklus budidaya sekaligus rumah budidaya.Kegiatan pendampingan yang telah dilakukan telah berhasil meningkatkan pengetahuan anggota kelompok tentang budidaya lele dengan sentuhan teknologi. Namun, hasil kegiatan ini tentu belum sempurna dikarenakan kendalakendala yang dihadapi, seperti komitmen anggota kelompok yang naik turun, ketidakpatuhan terhadap prosedur, dan lain-lain. Kegiatan ini tentu masih perlu per- baikan. Program ini akan berjalan dengan baik jika dikerjakan dengan perencanaan yang matang, pelaksanaan yang baik, monitoring yang rutin, dan evaluasi dari tiap kegiatan agar diperoleh kemajuan kegiatan yang lebih baik dengan mempelajari permasalahan yang ada sehingga diperoleh solusi yang terbaik.

\section{UCAPAN TERIMA KASIH}

Terima kasih kepada KEMENRISTEK DIKTI yang telah membiayai program pengabdian ini dan LPPM Universitas Teuku Umar, LPPM Universitas Syiah Kuala dan 
Pemerintahan Daerah Kabupaten Aceh Selatan yang telah memfasilitasi program pengabdian ini dan Kelompok kelompok UJOENG BATEE desa Blang Kuala, Kecamatan Meukek, Aceh Selatan atas kerjasamanya.

\section{REFERENSI}

Amanah S. 2005. Pengembangan responden pesisir berdasarkan kearifan lokal di pesisisr kabupaten Bulelelng di Provinsi Bali.[disertasi]. Bogor (ID) Sekolah Pascasarjana. Institut Pertanian Bogor.

Darmansyah A, Sulistiono, Nugroho T, Supriyono E. 2016). Pemberdayaan masyarakat melalui pengembangan budidaya ikan lele di Desa Balongan, Indramayu, Jawa Barat. Jurnal Agrokreatif IPB. 2(1): 8-16

Fatchiya A. 2010. Pola pengembangan kapasitas pembudidaya ikan kolam air tawar di Provinsi Jawa Barat. [disertasi]. Bogor (ID) Sekolah Pascasarjana. Institut Pertanian Bogor.

Ihsan YN. 2002. Kajian pengembangan budidaya laut (pengaruhnya terhadap kesejahteraan responden pesisir) studi kasus di kelurahan pulau panggang Kab. Seribu [Tesis]. Bogor (ID): Institut Pertanian
Bogor.

O'Brien D. 2001). Integrating Corporate Socia Responsibility Competitive Strategy J. Georgia (GE): mack robinson Collage of Business, Georgia State University

Press.Akhmad S. 2007. Membangun Gerakan Ekonomi Kolektif dalam Pertanian Berkelanjutan: Perlawanan terhadap liberalisasi dan oligopoli pasar produk pertanian tegalan. Jawa Tengah (ID). BABAD Purwokerto.

SlametM.2003.MembentukPolaPerilaku Manusia Pembangunan. Bogor (ID): IPB Press.

Sumardjo, Firmansyah A. 2015. Inovasi Pemberdayaan Masyarakat Berbasis Sumber Daya Pangan di Sekitar Wilayah Operasional PT. Pertamina EP Asset 3 Subang Field. Bogor (ID): CARE IPB.

Vasilescu R. 2010. Developing university social responcibility: a model for the challenges of the new civil society. Procedia social and behavioral sciences. 2(2): 4177-4182

Zulkarnain, 2015. Analisis Hubungan Jaringan Komunikasi Dengan Perubahan Taraf Penghidupan Dan Pola Pikir Dalam Pemberdayaan Pembudidaya Ikan Di Kabupaten Kampar, Riau. [disertasi]. Bogor (ID) Sekolah Pascasarjana. Institut Pertanian Bogor. 